\title{
PENERAPAN KURSUS LEARNING MANAGEMENT SYSTEM (LMS) BAGI PENINGKATAN KOMPETENSI GURU DAN TENAGA KEPENDIDIKAN PAUD
}

\author{
Jamaluddin $^{1 凶}$, Arie Martuty ${ }^{2}$ \& Mirawati Abdullah ${ }^{3}$ \\ ${ }^{1}$ Ilmu Pendidikan, Universitas Negeri Makassar \\ ${ }^{2}$ Pendidikan Guru Pendidikan Anak Usia Dini, Universitas Muhammadiyah Makassar \\ ${ }^{3}$ Bahasa Inggris, STIT Al Chaeriyah Mamuju
}

\begin{abstract}
:
Developments The world is currently faced with the phenomenon of digital disruption, which is a situation indicated by the movement of the industrial world or job competition that is no longer linear. In the field of courses, currently there has also been an online course service that can be accessed via the web/page. One is a Learning Management Systems (LMS) based course that allows instructors and/or students to share material, submit and return assignments, and communicate online. The research method used is research and development using the product development concept from ADDIE which consists of 5 stages, namely (1) analysis, (2) design, (3) development, (4) implementation, and (5) evaluation. The results of research and development of a Learning Management System (LMS)-based computer course model that has been tested on PAUD teachers and education staff show that the practicality of this model is very well implemented by instructors and can be applied by course organizers. The results of the course learning in the trial can improve the skills of PAUD teachers and education personnel in the office application computer course program.
\end{abstract}

Keywords: Course, Learning Management System, GTK PAUD

\begin{abstract}
Abstrak:
Perkembangan Dunia saat ini sedang dihadapkan pada fenomena disrupsi digital, yaitu situasi yang ditunjukkan oleh adanya pergerakan dunia industri atau persaingan kerja yang tidak lagi linier. Pada bidang kursus, saat ini juga telah memunculkan layanan kursus dalam jaringan yang dapat diakses melalui web/laman. Salah satu adalah kursus berbasis Learning Management Systems (LMS) yang memungkinkan instruktur dan/atau peserta didik untuk berbagi materi, menyerahkan dan mengembalikan tugas, dan berkomunikasi secara online. Metode Penelitian yang digunakan adalah Penelitian dan pengembangan dengan menggunakan konsep pengembangan produk dari ADDIE yang terdiri atas 5 tahapan, yaitu (1) analysis, (2) design, (3) development, (4) implementation, dan (5) evalution. Hasil penelitian dan pengembangan model kursus komputer berbasis Learning Manajemen System (LMS) yang telah diujicobakan pada guru dan tenaga kependidikan PAUD memperlihatkan bahwa tingkat kepraktisan model ini sangat baik dilaksanakan oleh instruktur dan dapat diterapkan oleh penyelenggara kursus. hasil pembelajaran kursus dalam ujicoba dapat meningkatkan keterampilan guru dan tenaga kependidikan PAUD pada program kursus komputer aplikasi perkantoran.
\end{abstract}

Kata Kunci: Kursus, Learning Manajemen System, GTK PAUD 


\section{PENDAHULUAN}

Kursus merupakan suatu kegiatan belajar-mengajar seperti halnya sekolah. Perbedaannya adalah bahwa kursus biasanya diselenggarakan dalam waktu pendek dan hanya untuk mempelajari satu keterampilan tertentu, Kursus saat ini banyak diselenggarakan oleh masyarakat, lembaga kursus, organisasi secara mandiri. dunia saat ini sedang dihadapkan pada fenomena disrupsi digital (digital disruption), yaitu situasi yang ditunjukkan oleh adanya pergerakan dunia industri atau persaingan kerja yang tidak lagi linier. Perubahan terjadi sangat cepat dan fundamental. Pola tatanan lama yang selama ini sudah mapan menjadi berantakan dalam waktu singkat dan tercipta pola tatanan baru. Di bidang pendidikan, era disrupsi telah mendorong bahkan "memaksa" terjadinya digitalisasi sistem pendidikan. Dalam hal ini, lembaga kursus dan pelatihan (LKP) sebagai satuan pendidikan nonformal dituntut untuk segera melakukan inovasi dari model pembelajaran konvensional (tatap muka) menjadi model pembelajaran dalam jaringan yang dirancang terbuka, dapat saling berbagi dan saling terhubung, atau berjejaring satu sama lain dengan memanfaatkan perkembangan teknologi informasi dan komunikasi secara produktif. Model pembelajaran dalam jaringan ini mengalami perubahan total yang memberikan pengalaman belajar lebih kreatif, partisipatif, beragam, dan menyeluruh tanpa harus tatap muka dalam ruang kelas. Pembelajaran kursus di era disrupsi yang sedang terjadi saat ini juga telah memunculkan layanan kursus dalam jaringan (daring) yang dapat diakses melalui web/laman penyedia layanan. Penyedia layanan tersebut tidak berupa satuan pendidikan, melainkan beberapa ahli dibidangnya bergabung dengan dengan beberapa ahli bidang teknologi informasi dan komunikasi membuat layanan kursus yang dapat diakses melalui perangkat elektronik seperti komputer, laptop dan perangkat komunikasi (smartphone). studi dokumentasi dari beberapa jurnal internasional terkait manfaat penggunaan Learning Management System pada kursus, dikatakan bahwa sebuah studi tentang bagaimana menggunakan aplikasi E-learning (Learning Management System Moodle) dalam proses pengajaran universitas penelitian yang ditulis oleh (Oproiu, 2015) disebutkan bahwa kelebihan pembelajaran menggunakan Learning Management System ini diantaranya adalah hal-hal berikut: (1) Staf pengajar memiliki kontak yang lebih lancar dengan peserta didik yang mendaftar untuk kursus, oleh kelas virtual yang dibuat. (2) memungkinkan topik laboratorium dan seminar atau daftar pustaka yang diperlukan dapat dimuat dalam lingkungan dimana kursus. (3) Ruang dimana data peserta didik dapat dengan mudah ditangani (sekretariat virtual) dapat dibentuk. (4) memberikan penilaian pengetahuan dan peluang penilaian diri dengan pengujian online. (5) memungkinkan komunikasi dan sosialisasi yang baik melalui obrolan atau forum, baik antara peserta pelatihan dan dengan staf pengajar. Komunikasi individu dengan staf pengajar dapat dicapai atau topik dapat diperdebatkan oleh semua anggota yang mengakses aplikasi Learning Management System. Apa membuat Learning Management System (LMS) unik adalah sifat instruksionalnya. Learning Management System (LMS) menyediakan tempat untuk belajar dan mengajar kegiatan yang terjadi dalam lingkungan yang mulus, yang tidak tergantung pada waktu dan batas ruang (Ullman \& Rabinowitz, 2004). Sistem ini memungkinkan lembaga pendidikan untuk mengelola sejumlah besar sepenuhnya online atau dicampur (bagian online dan bagian tatap muka) menggunakan kursus antarmuka umum dan serangkaian sumber daya. Tatap muka menghadapi kursus yang menggunakan LMS untuk wajib atau kegiatan tambahan sering disebut sebagai kursus webdisempurnakan (Schmidt, 2002).

Hasil studi pendahuluan oleh peneliti melalui metode survei dengan menggunakan instrumen/angket online berbasis google form, terkait pembelajaran online yang diselenggarakan oleh lembaga kursus dan pelatihan diperoleh data, hanya $15 \%$ lembaga kursus dan pelatihan telah melaksanakan pembelajaran dalam jaringan dan $85 \%$ masih 
memberikan layanan kursus dan pelatihan yang konvensional, baik dari sisi layanan maupun dalam proses pembelajaran. Pengambilan data juga dilakukan melalui observasi dan wawancara langsung terkait pelaksanaan kursus berbasis Learning Manajemen System (LMS). Berdasarkan hasil observasi dan wawancara belum ada lembaga kursus dan pelatihan yang menyelenggarakan kursus dan pelatihan berbasis Learning Manajemen System. Hal ini disebabkan beberapa masalah yang dihadapi oleh lembaga kursus dan pelatihan yaitu (1) jaringan internet yang tidak ada, (2) peserta didik belum memiliki perangkat elektronik untuk mengakses pembelajaran kursus dalam jaringan (online), (3) biaya yang digunakan untuk mengadakan perangkat dan jaringan internet mahal, serta (4) pendidik (instruktur) yang belum memahami pembelajaran dalam jaringan utamanya yang berbasis Learning Manajemen System (LMS). sekaitan dengan hal tersebut, kemudian dirancang sebuah model kursus berbasis Learning Management System (LMS) dengan mengambil responden guru dan tenaga Kependidikan PAUD dan melaksanakan ujicoba program kursus komputer aplikasi perkantoran.

\section{METODE PENELITIAN}

Pendekatan dan Jenis penelitian yang akan digunakan adalah penelitian dan pengembangan dengan menggunakan konsep pengembangan produk dari ADDIE Menurut Branch (2009:2) yang terdiri atas 5 tahapan, yaitu (1) analysis, (2) design, (3) development, (4) implementation, dan (5) evalution. Ruang lingkup penelitian ini adalah mengetahui tingkat validasi, tingkat kepraktisan dan tingkat efektifitas model pembelajaran kursus dan pelatihan berbasis Learning Manajemen System. Teori-teori yang digunakan adalah sebagai berikut; 1) Konstruktivisme Kognitif berdasarkan Jean Piaget, (1965), dan 2) Konstruktivisme Sosial berdasarkan Lev Vygotsky, (1925a) .3) Progressivisme yang menyatakan bahwa manusia memiliki kemampuan untuk mengembangkan dan menyempurnakan lingkungannya dengan menerapkan kecerdasan yang dimilikinya (Gerald Lee Gutek, 2010), 4) Learning Management Systems (LMS) adalah sistem berbasis web yang memungkinkan instruktur dan / atau siswa untuk berbagi materi, menyerahkan dan mengembalikan tugas, dan berkomunikasi secara online (Lonn and Teasley, 2009).

Teknik pengumpulan data dilakukan sesuai dengan tahapan dalam prosedur pengembangan model ini adalah tahap analisis (analyze) teknik pengumpulan data yang digunakan adalah menggunakan angket/kuesioner berbasis google form, kemudian dilakukan wawancara tidak terstruktur, dan dilakukan observasi langsung ke lembaga kursus dan pelatihan, tahap penyusunan desain (design), teknik pengumpulan data yang digunakan adalah diskusi, fokus group diskusi, tahap pengembangan (development) teknik pengumpulan data yang digunakan adalah Angket yang akan diisi oleh validator ahli media, validator ahli materi, validator ahli bahasa, tahap implementasi (implementation) teknik pengumpulan data yang digunakan adalah Angket yang akan diisi oleh Instruktur dan peserta, dan pada tahap evaluasi (evaluation) teknik pengumpulan data yang digunakan adalah angket yang akan diisi oleh pendidik dan tenaga kependidikan kursus dan pelatihan terkait evaluasi pelaksanaan pembelajaran oleh instruktur, dan instrumen pretest dan posttest untuk mengukur efektifitas model pembelajaran yang telah diberikan kepada peserta. 
Teknik analisis data dilakukan dengan cara analisis data kualitatif dan analisis data kuantitatif untuk setiap tahapan dalam prosedur penelitian ini adalah tahap Analisis (analyze) teknik analisis data yang digunakan adalah kualitatif dan kuantitatif. Instrumen studi pendahuluan yang telah diisi oleh responden; 1) penyelenggara kursus dan pelatihan, terkait pelaksanaan kursus dan pelatihan yang telah dilaksanakan, baik secara online maupun offline. 2). Instruktur terkait penggunaan aplikasi Learning Management System dalam pembelajaran. Pada tahap penyusunan desain (design), teknik analisis data yang digunakan adalah kualitatif. Pada tahap pengembangan (development) teknik analisis data yang digunakan adalah kualitatif dan kuantitatif. instrumen validasi yang telah berikan dan telah diisi oleh validator ahli media, validator ahli materi dan validator bahasa kemudian dilakukan analisis dan menghasilkan data dalam bentuk data kualitatif.

Pada tahap implementasi (implementation) teknik analisis data yang digunakan adalah kualitatif dan kuantitatif. Instrumen pengumpulan data yang diisi oleh Instruktur pada aspek penggunaan model kursus dan pelatihan berbasis aplikasi Learning Management System Google Classroom, Hasil analisis data dalam bentuk data kuantitatif dan data kualitatif. Pada tahap evaluasi (evaluation) teknik analisis data yang digunakan adalah kualitatif dan kuantitatif. Instrumen pengumpulan data yang diisi oleh peserta pada aspek penggunaan dan pemanfaatan model kursus dan pelatihan berbasis aplikasi Learning Management System Google Classroom sebagai media pembelajaran. Serta hasil pretest dan posttest peserta setelah mengikuti model pembelajaran. Hasil analisis data dalam bentuk data kuantitatif dan data kualitatif.

\section{HASIL DAN PEMBAHASAN}

Hasil penelitian menunjukkan validasi dilakukan lima (5) orang ahli/pakar/praktisi merupakan kegiatan penilaian para ahli terhadap produk model pembelajaran yang telah dibuat. Para ahli diminta untuk memvalidasi semua produk model yang telah dibuat pada tahap sebelumnya. Saran dari para ahli/pakar/praktisi digunakan sebagai acuan dalam revisi produk model. Kategorisasi validitas model dikutip dari Sugiyono (2017:165) sebagai berikut:

Tabel 1. Kategorisasi Validitas

\begin{tabular}{ll}
\hline Sangat Tidak Valid (STV) jika skor & $: 0 \leq \overline{\boldsymbol{x}} \leq 1$ \\
\hline Tidak Valid (TV) jika skor & $: 1 \leq \overline{\boldsymbol{x}} \leq 2$ \\
\hline Cukup Valid (CV) jika skor & $: 2 \leq \overline{\boldsymbol{x}} \leq 3$ \\
\hline Valid (V) jika skor & $: 3 \leq \overline{\boldsymbol{x}} \leq 4$ \\
\hline Sangat Valid (SV) jika skor & $: 4 \leq \overline{\boldsymbol{x}} \leq 5$ \\
\hline
\end{tabular}

Tabel 2 Rata-rata Hasil Validasi Ahli Materi Buku Model dan Kurikulum

\begin{tabular}{llcl}
\hline \multicolumn{1}{c}{ Aspek Penilaian } & (Ai) & Ket \\
\hline 1. & Komponen Buku Model & 4,2 & SV \\
\hline 2. & Kurikulum & 4,1 & SV \\
\hline 3. & Isi Materi & 4,2 & SV \\
\hline 4. & Pembelajaran & 4,3 & SV \\
\hline
\end{tabular}




\begin{tabular}{rrrr}
\hline \multicolumn{2}{c}{ Aspek Penilaian } & (Ai) & Ket \\
\hline 5. Interaksi dan Umpan Balik & & 3,7 & $\mathrm{~V}$ \\
\hline & Jumlah Nilai & 20,5 & \\
\hline & Rata-rata & 4,09 & SV \\
\hline
\end{tabular}

Nilai rata-rata total kevalidan buku model dan kurikulum menurut validator ahli materi untuk seluruh aspek penilaian diperoleh $\overline{\boldsymbol{x}}=4,09$ berdasarkan kriteria kevalidan yang disebutkan diatas, nilai ini termasuk dalam kategori Sangat Valid (SV) yaitu berada pada 4 $\leq \overline{\boldsymbol{x}} \leq 5$. Jika ditinjau dari seluruh aspek format ini, maka buku model dan kurikulum model kursus dan pelatihan komputer aplikasi perkantoran berbasis LMS dalam mendukung SDM guru PAUD yang terampil dinyatakan memenuhi kriteria kevalidan.

Tabel 3 Rata-rata Hasil Validasi Ahli Media pada Buku Model dan Kurikulum

\begin{tabular}{llcc}
\hline \multicolumn{1}{c}{ Aspek Penilaian } & (Ai) & Ket \\
\hline 1. & Komponen Kelayakan Kegrafikaan & 3,8 & $\mathrm{~V}$ \\
\hline 2. & Desain Cover Buku & 3,4 & $\mathrm{~V}$ \\
\hline 3. & $\begin{array}{l}\text { Tipografi Cover Buku - Huruf yang } \\
\text { digunakan menarik dan mudah dibaca }\end{array}$ & 3,9 & $\mathrm{~V}$ \\
\hline 4. & $\begin{array}{l}\text { Ilustrasi Kulit Buku - Mencerminkan isi } \\
\text { buku }\end{array}$ & 3,3 & $\mathrm{~V}$ \\
\hline 5. Desain Isi Buku - Tata Letak Isi Buku & 3,6 & $\mathrm{~V}$ \\
\hline 6. Desain Isi Buku - Tipografi Isi Buku & 3,9 & $\mathrm{~V}$ \\
\hline & Jumlah Nilai & 21,9 & $\mathrm{~V}$ \\
\hline
\end{tabular}

Nilai rata-rata total kevalidan buku model dan kurikulum menurut validator ahli media untuk seluruh aspek penilaian diperoleh $\overline{\boldsymbol{x}}=3,65$ berdasarkan kriteria kevalidan yang disebutkan diatas, nilai ini termasuk dalam kategori Valid (V) yaitu berada pada $3 \leq \overline{\boldsymbol{x}} \leq 4$. Jika ditinjau dari seluruh aspek format ini, maka buku model dan kurikulum model kursus dan pelatihan komputer aplikasi perkantoran berbasis LMS dalam mendukung SDM guru PAUD yang terampil dinyatakan memenuhi kriteria kevalidan.

Tabel 4 Rata-rata Hasil Validasi Ahli Media pada Aplikasi LMS Google Classroom

\begin{tabular}{rlcc}
\hline \multicolumn{1}{c}{ Aspek Penilaian } & $(\mathbf{A i})$ & Ket \\
\hline 1. & Komponen Kelayakan Aplikasi & 3,7 & $\mathrm{~V}$ \\
\hline 2. & Aspek Rekayasa Perangkat Lunak & 3,9 & $\mathrm{~V}$ \\
\hline 3. & Aspek Komunikasi Visual & 3,9 & $\mathrm{~V}$ \\
\hline 4. & Aspek Aplikasi LMS - Google Classroom & 3,9 & $\mathrm{~V}$ \\
\hline \multicolumn{2}{r}{ Jumlah Nilai } & 15,4 & \\
\hline & Rata-rata & 3,85 & $\mathrm{~V}$ \\
\hline
\end{tabular}


Nilai rata-rata total kevalidan Aplikasi LMS Google Classroom menurut validator ahli media untuk seluruh aspek penilaian diperoleh $\overline{\boldsymbol{x}}=3,85$ berdasarkan kriteria kevalidan yang disebutkan diatas, nilai ini termasuk dalam kategori Valid (V) yaitu berada pada $3 \leq \overline{\boldsymbol{x}} \leq 4$. Jika ditinjau dari seluruh aspek format ini, maka Aplikasi LMS Google Classroom pada model dan kurikulum model kursus dan pelatihan komputer aplikasi perkantoran berbasis LMS dalam mendukung SDM guru PAUD yang terampil dinyatakan memenuhi kriteria kevalidan.

Tabel 5 Rata-rata Hasil Validasi Ahli Materi pada Buku Panduan bagi Instruktur

\begin{tabular}{clccc}
\hline No & \multicolumn{1}{c}{ Aspek Penilaian } & $(\mathbf{A i})$ & $\overline{\boldsymbol{x}}$ & Ket \\
\hline 1 & $\begin{array}{l}\text { Pembelajaran Berbasis Learning } \\
\text { Manajemen System (LMS) }\end{array}$ & 4,00 & 4,00 & $\mathrm{SV}$ \\
\hline 2 & $\begin{array}{l}\text { Penggunaan Aplikasi LMS pada Kursus dan } \\
\text { Pelatihan }\end{array}$ & 4,00 & 4,00 & $\mathrm{SV}$ \\
\hline 3 & Interface (Tampilan Aplikasi LMS) & 4,00 & 4,00 & $\mathrm{SV}$ \\
\hline 4 & Desain Grafis dan Audio Visual & 4,00 & 4,00 & $\mathrm{SV}$ \\
\hline$\quad$ Jumlah Nilai & & 16,00 & \\
\hline & Rata-rata & & 4,00 & $\mathrm{SV}$ \\
\hline
\end{tabular}

Untuk nilai rata-rata total kevalidan Buku Panduan bagi Instruktur menurut validator ahli materi untuk seluruh aspek penilaian diperoleh $\overline{\boldsymbol{x}}=4,00$ berdasarkan kriteria kevalidan yang disebutkan diatas, nilai ini termasuk dalam kategori Sangat Valid (SV) yaitu berada pada $4 \leq \overline{\boldsymbol{x}} \leq 5$. Jika ditinjau dari seluruh aspek format ini, maka Buku Panduan bagi Instruktur dinyatakan memenuhi kriteria kevalidan.

Tabel 6 Rata-rata Hasil Validasi Ahli Bahasa pada Buku Model, Kurikulum dan Buku Pedoman

\begin{tabular}{clcc}
\hline No & \multicolumn{1}{c}{ Aspek Penilaian } & (Ai) & Ket \\
\hline 1 & Kebahasaan pada Buku Model & 4,90 & SV \\
\hline 2 & Kebahasaan pada Kurikulum Model & 4,90 & SV \\
\hline 3 & Kebahasaan pada Buku Panduan Bagi Pengelola LKP & 4,95 & SV \\
\hline 4 & Kebahasaan pada Buku Panduan Bagi Instruktur & 4,95 & SV \\
\hline 5 & Kebahasaan pada Buku Panduan Bagi Peserta Didik & 5,00 & SV \\
\hline & Jumlah Nilai & 24,70 \\
\hline & Rata-rata & 4,94 & SV
\end{tabular}

Untuk nilai rata-rata total kevalidan untuk aspek Bahasa pada Buku Model, Kurikulum dan Buku Panduan seluruh aspek penilaian diperoleh $\overline{\boldsymbol{x}}=4,94$ berdasarkan kriteria kevalidan yang disebutkan diatas, nilai ini termasuk dalam kategori Sangat Valid (SV) yaitu berada pada $4 \leq \overline{\boldsymbol{x}} \leq 5$. Jika ditinjau dari seluruh aspek format ini, maka untuk aspek Bahasa pada Buku Model, Kurikulum dan Buku Panduan dinyatakan memenuhi kriteria kevalidan. 
Uji kepraktisan dalam ujicoba model ini menggunakan dua instrumen, yaitu angket kepraktisan setiap materi yang diberikan oleh instruktur yang diisi oleh peserta didik terkait kepraktisan model pembelajaran kursus dan pelatihan komputer aplikasi perkantoran berbasis LMS (google classroom) yang diajarkan oleh instruktur, dan angket kepraktisan setiap materi yang diisi oleh instruktur terkait pengelolaan model pembelajaran kursus dan pelatihan komputer aplikasi perkantoran berbasis LMS (google classroom) dalam mendukung Sumber Daya Manusia guru Pendidikan Anak Usia Dini yang terampil. Kriteria penilaian oleh peserta didik dengan memberikan nilai pada instrumen dengan keterangan sebagai berikut: 4 = Sangat Setuju, $3=$ Setuju, $2=$ Kurang Setuju, dan $1=$ Tidak Setuju. Hasil pengisian angket kepraktisan ini digambarkan sebagai berikut:

\begin{tabular}{|c|c|c|c|c|c|c|c|c|c|c|c|c|c|c|c|c|c|}
\hline P1 & M1 & $\%$ & M2 & $\%$ & M3 & $\%$ & M4 & $\%$ & M5 & $\%$ & M6 & $\%$ & M7 & $\%$ & M8 & $\%$ & $\begin{array}{c}\text { Rata- } \\
\text { rata }\end{array}$ \\
\hline $\begin{array}{l}\text { Sangat } \\
\text { Setuju }\end{array}$ & 16 & 53,33 & 14 & 46,67 & 12 & 40,00 & 13 & 43,33 & 20 & 66,67 & 17 & 56,67 & 17 & 56,67 & 16 & 53,33 & 52,08 \\
\hline Setuju & 14 & 46,67 & 15 & 50,00 & 15 & 50,00 & 17 & 56,67 & 10 & 33,33 & 12 & 40,00 & 13 & 43,33 & 13 & 43,33 & 45,42 \\
\hline $\begin{array}{c}\text { Kurang } \\
\text { Setuju }\end{array}$ & 0 & 0,00 & 1 & 3,33 & 2 & 6,67 & 0 & 0,00 & 0 & 0,00 & 1 & 3,33 & 0 & 0,00 & 1 & 3,33 & 2,08 \\
\hline $\begin{array}{l}\text { Tidak } \\
\text { Setuju }\end{array}$ & 0 & 0,00 & 0 & 0,00 & 1 & 3,33 & 0 & 0,00 & 0 & 0,00 & 0 & 0,00 & 0 & 0,00 & 0 & 0,00 & 0,42 \\
\hline & 30 & & 30 & & 30 & & 30 & & 30 & & 30 & & 30 & & 30 & & \\
\hline
\end{tabular}

Hasil pengisian angket respon peserta didik dari keseluruhan materi untuk pertanyaan pertama, didapatkan data rata-rata $52,08 \%$ peserta didik mengatakan Sangat Setuju, 45,42\% peserta didik mengatakan Setuju, 2,08 \% peserta didik mengatakan Kurang Setuju dan $0,42 \%$ peserta didik mengatakan tidak setuju. Hasil pengisian angket respon peserta didik dari keseluruhan materi untuk pertanyaan kedua, didapatkan data rata-rata 62,92\% peserta didik mengatakan Sangat Setuju, 34,58\% peserta didik mengatakan Setuju, 2,50\% peserta didik mengatakan Kurang Setuju dan $0 \%$ peserta didik mengatakan Tidak Setuju.

Hasil pengisian angket respon peserta didik dari keseluruhan materi untuk pertanyaan ketiga, didapatkan data rata-rata 49,17\% peserta didik mengatakan Sangat Setuju, 45,83\% peserta didik mengatakan Setuju, 4,58\% peserta didik mengatakan Kurang Setuju dan $0,42 \%$ peserta didik mengatakan tidak setuju. Hasil pengisian angket respon peserta didik dari keseluruhan materi untuk pertanyaan keempat, didapatkan data rata-rata 54,17\% peserta didik mengatakan Sangat Setuju, 42,50\% peserta didik mengatakan Setuju, 2,08\% peserta didik mengatakan Kurang Setuju dan 1, 25\% peserta didik mengatakan Tidak Setuju. Hasil pengisian angket respon peserta didik dari keseluruhan materi untuk pertanyaan kelima, didapatkan data rata-rata $60,00 \%$ peserta didik mengatakan Sangat Setuju, 37,92\% peserta didik mengatakan Setuju, 1,67\% peserta didik mengatakan Kurang Setuju dan 0, 42\% peserta didik mengatakan Tidak Setuju. Hasil pengisian angket respon peserta didik dari keseluruhan materi untuk pertanyaan keenam, didapatkan data rata-rata $51,67 \%$ peserta didik mengatakan Sangat Setuju, 44,17\% peserta didik mengatakan Setuju, 4,17\% peserta didik mengatakan Kurang Setuju dan 0\% peserta didik mengatakan Tidak Setuju. Hasil pengisian angket respon peserta didik dari keseluruhan materi untuk pertanyaan ketujuh, didapatkan data rata-rata $52,08 \%$ peserta didik mengatakan Sangat Setuju, 43,33\% peserta didik mengatakan Setuju, 4,58\% peserta didik mengatakan Kurang Setuju dan $0 \%$ peserta didik mengatakan Tidak Setuju. 
Hasil pengisian angket respon peserta didik dari keseluruhan materi untuk pertanyaan kedelapan, didapatkan data rata-rata $57,08 \%$ peserta didik mengatakan Sangat Setuju, 40,42\% peserta didik mengatakan Setuju, 2,50\% peserta didik mengatakan Kurang Setuju dan $0 \%$ peserta didik mengatakan Tidak Setuju. Hasil pengisian angket respon peserta didik dari keseluruhan materi untuk pertanyaan kesembilan, didapatkan data rata-rata 58,75\% peserta didik mengatakan Sangat Setuju, 39,58\% peserta didik mengatakan Setuju, 1,67\% peserta didik mengatakan Kurang Setuju dan 0\% peserta didik mengatakan Tidak Setuju. Hasil pengisian angket respon peserta didik dari keseluruhan materi untuk pertanyaan kesepuluh, didapatkan data rata-rata $50,42 \%$ peserta didik mengatakan Sangat Setuju, 45,42\% peserta didik mengatakan Setuju, 3,33\% peserta didik mengatakan Kurang Setuju dan $0,83 \%$ peserta didik mengatakan Tidak Setuju.

Uji efektifitas dalam penelitian ini mengambil data dari desain One-Group PretestPosttest Design. Pengambilan data hasil efektifitas ini diukur dengan menggunakan hasil pretest yang dilakukan sebelum diberikan perlakuan dan posttest yang dilakukan setelah diberikan perlakuan untuk setiap seri pembelajaran. Dengan demikian hasil perlakuan dapat diketahui lebih akurat. Untuk menghilangkan bias dari hasil penelitian, maka pretest dan posttest akan dilakukan selama empat sesi materi pembelajaran. Skema One-Group Pretest-Posttest Design. Hasil Uji Paired Sample T Test untuk sesi 1 ini, didapatkan nilai signifikansi (2-tailed) $=0,001$. Hal ini menandakan bahwa nilai signifikansi (2-tailed) < 0,05, sehingga Ho ditolak dan Ha diterima. Artinya Ada perbedaan rata-rata antara hasil belajar pretest dan posttest sesi 1, dan ini berarti ada pengaruh model kursus dan pelatihan berbasis LMS dalam meningkatkan hasil belajar dan keterampilan komputer aplikasi perkantoran bagi Guru Pendidikan Anak Usia Dini sesi 1. Hasil Uji Paired Sample T Test untuk sesi 2 ini, didapatkan nilai signifikansi (2-tailed) $=0,000$. Hal ini menandakan bahwa nilai signifikansi (2-tailed) $<0,05$, sehingga Ho ditolak dan Ha diterima. Artinya Ada perbedaan rata-rata antara hasil belajar pretest dan posttest pada sesi 2, dan ini berarti ada pengaruh model kursus dan pelatihan berbasis LMS dalam meningkatkan hasil belajar dan keterampilan komputer aplikasi perkantoran bagi Guru Pendidikan Anak Usia Dini pada sesi 2.

Hasil Uji Paired Sample T Test untuk sesi 3 ini, didapatkan nilai signifikansi (2-tailed) $=0,000$. Hal ini menandakan bahwa nilai signifikansi (2-tailed) $<0,05$, sehingga Ho ditolak dan Ha diterima. Artinya Ada perbedaan rata-rata antara hasil belajar pretest dan posttest pada sesi 3, dan ini berarti ada pengaruh model kursus dan pelatihan berbasis LMS dalam meningkatkan hasil belajar dan keterampilan komputer aplikasi perkantoran bagi Guru Pendidikan Anak Usia Dini pada sesi 3. Hasil Uji Paired Sample T Test untuk sesi 4 ini, didapatkan nilai signifikansi (2-tailed) $=0,005$. Hal ini menandakan bahwa nilai signifikansi (2-tailed) $<0,05$, sehingga Ho ditolak dan Ha diterima. Artinya Ada perbedaan rata-rata antara hasil belajar pretest dan posttest pada sesi 4, dan ini berarti ada pengaruh model kursus dan pelatihan berbasis LMS dalam meningkatkan hasil belajar dan keterampilan komputer aplikasi perkantoran bagi Guru Pendidikan Anak Usia Dini pada sesi 4.

Berdasarkan prosedur pengembangan model ADDIE yang gunakan dalam penelitian ini, maka pada bagian pembahasan hasil penelitian ini akan dikemukakan tiga hal yang berkaitan dengan pengembangan Model Kursus Dan Pelatihan Komputer Aplikasi 
Perkantoran Berbasis LMS dalam mendukung SDM Guru Pendidikan Anak Usia Dini yang Terampil, yaitu: (1) ketercapaian tujuan penelitian, (2) keterbatasan-keterbatasan penelitian, dan (3) Temuan-temuan khusus.

Pembahasan hasil penelitian ini akan mengupas empat hal yang berkaitan dengan pengembangan model kursus dan pelatihan komputer aplikasi perkantoran berbasis LMS dalam mendukung SDM Guru Pendidikan Anak Usia Dini yang terampil, yaitu: (1) gambaran tingkat kebutuhan model kursus dan pelatihan komputer aplikasi perkantoran berbasis LMS, (2) desain model kursus dan pelatihan komputer aplikasi perkantoran berbasis LMS, (3) mengetahui tingkat validitas model kursus dan pelatihan komputer aplikasi perkantoran berbasis LMS (4) mengetahui tingkat kepraktisan dan tingkat efektifitas model kursus dan pelatihan komputer aplikasi perkantoran berbasis LMS. Keempat bagian tersebut adalah:

1. Gambaran Kebutuhan Lapangan Pengembangan Model Kursus dan Pelatihan Komputer Aplikasi Perkantoran Berbasis LMS.

2. Gambaran Desain Pengembangan Model kursus dan pelatihan komputer aplikasi perkantoran berbasis LMS.

3. Mengetahui Tingkat Validitas dan Tingkat kepraktisan Model kursus dan pelatihan komputer aplikasi perkantoran berbasis LMS.

4. Mengetahui Tingkat Keefektifan Model Pengembangan kepraktisan Model kursus dan pelatihan komputer aplikasi perkantoran berbasis LMS dalam mendukung Sumber Daya Manusia Guru Pendidikan Anak Usia Dini yang terampil.

Beberapa keterbatasan dalam penelitian ini mulai dari naskah produk model, yang terdiri dari buku model, kurikulum, panduan bagi pengelola, panduan bagi instruktur dan panduan bagi peserta didik yang masih berupa teks tradisional dan belum banyak dilengkapi gambar-gambar pendukung dari teks tersebut. Tentunya keterbatasan ini akan disempurnakan pada tahap selanjutnya. Selanjutnya keterbatasan penelitian ini adalah program kursus dan pelatihan yang dibuat pada proses ujicoba hanya terdiri satu jenis kursus dan pelatihan yaitu program komputer aplikasi perkantoran. Tentunya model ini tidak hanya dapat digunakan oleh kursus dan pelatihan tertentu, namun dapat diterapkan oleh semua satuan pendidikan non formal, mulai dari lembaga kursus dan pelatihan (LKP), Pusat kegiatan belajar masyarakat (PKBM), sanggar kegiatan belajar (SKB) dan penyelenggara-penyelenggara pendidikan non formal yang tidak terlembaga namun memiliki komitmen untuk ikut berkonstribusi dalam mencerdaskan kehidupan bangsa di negara tercinta Republik Indonesia ini.

Beberapa kendala dan temuan khusus dalam proses pelaksanaan ujicoba dalam penelitian ini, adalah implementasi model pembelajaran kursus dan pelatihan ini akan berjalan dengan baik, jika didukung oleh semua pihak, mulai dari instruktur, penyelenggara, peserta didik. Dukungan disini mulai dari proses persiapan pembelajaran, proses pelaksanaan pembelajaran, proses evaluasi. Aktivitas penyelenggara dimulai dari mengelola kelas, berinteraksi dengan peserta didik, interaksi dengan instruktur sangat membutuhkan keterampilan-keterampilan yang terkait dengan teknologi informasi dan komunikasi, mulai dari penggunaan laptop, handphone, dan koneksi internet. 


\section{KESIMPULAN}

Kesimpulan yang dapat ditarik dari penelitian dan pengembangan ini adalah Tingkat kevalidan untuk semua aspek, mulai aspek materi, aspek media dan aspek bahasa pada produk buku model, kurikulum, buku panduan bagi pengelola LKP, buku panduan bagi instruktur, dan buku panduan bagi peserta didik memenuhi kriteria kevalidan. Tingkat kepraktisan model oleh instruktur rata-rata setuju hingga sangat setuju mulai aspek kejelasan petunjuk penggunaan rencana pelaksanaan pembelajaran pada model kursus dan pelatihan berbasis LMS, aspek ketercapaian kompetensi dan tujuan pembelajaran model kursus dan pelatihan berbasis LMS, aspek respon peserta didik pada saat pembelajaran di model kursus dan pelatihan berbasis LMS, aspek tingkat kesulitan instruktur dalam mengimplementasikan model kursus dan pelatihan berbasis LMS. Tingkat efektivitas model dari empat sesi pembelajaran yang diberikan, diperoleh hasil perbedaan rata-rata antara hasil belajar pretest dan posttest untuk semua sesi, dan ini berarti ada pengaruh model kursus dan pelatihan berbasis LMS dalam meningkatkan hasil belajar dan keterampilan komputer aplikasi perkantoran bagi guru pendidikan anak usia dini untuk semua sesi pembelajaran.

\section{DAFTAR PUSTAKA}

Alias, N.A., Zainuddin, A.M., 2005. Innovation for Better Teaching and Learning: Adopting the Learning Management System 14.

Almarashdeh, I., 2016. Sharing instructors experience of learning management system: A technology perspective of user satisfaction in distance learning course. Comput. Hum. Behav. 63, 249-255. https://doi.org/10.1016/j.chb.2016.05.013

Al-Neklawy, A.F., 2017b. Online Embryology teaching using learning management systems appears to be a successful additional learning tool among Egyptian medical students. Ann. Anat. - Anat. Anz. 214, 9-14. https://doi.org/10.1016/j.aanat.2017.07.001

Arikunto, S, 2008. Prosedur Penelitian Suatu Pendekatan Praktik. Rineka Karya, Jakarta.

Branch, R.M., 2009. Instructional Design: The ADDIE Approach. Springer US, Boston, MA. https://doi.org/10.1007/978-0-387-09506-6

Cantabella, M., Martínez-España, R., Ayuso, B., Yáñez, J.A., Muñoz, A., 2019. Analysis of student behavior in learning management systems through a Big Data framework. Future Gener. Comput. Syst. 90, 262-272. https://doi.org/10.1016/j.future.2018.08.003

Conde, M.A., García, F., Rodríguez-Conde, M.J., Alier, M., García-Holgado, A., 2014. Perceived openness of Learning Management Systems by students and teachers in education and technology courses. Comput. Hum. Behav. 31, 517-526. https://doi.org/10.1016/j.chb.2013.05.023

Dick, W., Carey, L., Carey, J.O., 2015. The systematic design of instruction, Eighth edition. ed. Pearson, Boston.

Elfeky, A.I.M., Masadeh, T.S.Y., Elbyaly, M.Y.H., 2020. Advance organizers in flipped classroom via e-learning management system and the promotion of integrated 
science process skills. Think. Ski. Creat. 35, 100622. https://doi.org/10.1016/j.tsc.2019.100622

Gerald Lee Gutek, 2010. Philosophical Alternative In Education. Loyola University of Chicago.

Hutchison, A., 2019. Technological Efficiency in The Learning Management System: A Wicked Problem with Sustainability for Online Writing Instruction. Comput. Compos. 54, 102510. https://doi.org/10.1016/j.compcom.2019.102510

Kats, Y. (Ed.), 2010. Learning Management System Technologies and Software Solutions for Online Teaching: Tools and Applications. IGI Global. https://doi.org/10.4018/978-1-61520-853-1

Larochelle, M., Bednarz, N., Garrison, J.W. (Eds.), 1998. Constructivism and education. Cambridge University Press, Cambridge; New York.

Lonn, S., Teasley, S.D., 2009. Saving time or innovating practice: Investigating perceptions and uses of Learning Management Systems. Comput. Educ. 53, 686-694. https://doi.org/10.1016/j.compedu.2009.04.008

Mozhaeva, G., Feshchenko, A., Kulikov, I., 2014. E-learning in the Evaluation of Students and Teachers: LMS or Social Networks? Procedia - Soc. Behav. Sci. 152, $127-$ 130. https://doi.org/10.1016/j.sbspro.2014.09.168

Oproiu, G.C., 2015. A Study about Using E-learning Platform (Moodle) in University Teaching Process. Procedia - Soc. Behav. Sci. 180, 426-432. https://doi.org/10.1016/j.sbspro.2015.02.140

Ramírez-Correa, P.E., Rondan-Cataluña, F.J., Arenas-Gaitán, J., Alfaro-Perez, J.L., 2017. Moderating effect of learning styles on a learning management system's success. Telemat. Inform. 34, 272-286. https://doi.org/10.1016/j.tele.2016.04.006

Sugiyono, 2017. Metode Penelitian dan Pengembangan (research and development) untuk bidang Pendidikan, Manajemen, Sosial, Teknik. CV. ALFABETA, Bandung, p. 712 .

Sugiyono, 2013. Metode Penelitian Pendidikan. Pendekatan Kuantitatif, Kualitatif, dan R\&D. CV. ALFABETA, Bandung, p. 458.

Walter R. Borg, Meredith D. Gall, Joyce P. Gall, 2003. Educational Research An Introduction, 7th Edition. ed. Pearson Education Inc. Boston USA.

Weaver, D., Spratt, C., Nair, C.S., 2008. Academic and student use of a learning management system: Implications for quality. Australas. J. Educ. Technol. 24. https://doi.org/10.14742/ajet.1228 